\title{
ANALISIS KETIMPANGAN DISTRIBUSI PENDAPATAN 33 PROVINSI DI INDONESIA
}

\author{
Galaxi Chrisamba \\ Birgitta Dian Saraswati \\ Universitas Kristen Satya Wacana \\ birgitta.saraswati@staff.uksw.edu
}

\begin{abstract}
This study aims to determine the factors that influence the unequality distribution of income in Indonesia. This study uses panel data with the time of year during the period 2007-2012 and cross section 33 provinces in Indonesia. Through the fixed effect estimation model result that inflation is negative and significant effect on the unequality distribution of income and education while government spending and a significant positive effect on the unequality distribution of income.
\end{abstract}

Keywords: Inflation, education, goverment spending, fixed effect$$
\text { PENDAHULUAN }
$$

"Pertumbuhan ekonomi yang tinggi itu membanggakan, tetapi pemerataan pendapatanlah yang membuat sebuah negara itu mencapai kebahagiaan". Hanya saja terkadang sebuah negara melupakan salah satunya yaitu pemerataan distribusi pendapatan. Pemerataan distribusi pendapatan merupakan hal yang penting di dalam sebuah negara. Sofyan (2010) mengemukakan bahwa kegagalan pemerataan distribusi pendapatan tidak hanya berpengaruh buruk terhadap bidang perekonomian saja, tetapi juga sosial, politik dan keamanan. Ketimpangan pendapatan akan menyebabkan tumbuhnya kecemburuan sosial dan kemiskinan yang nantinya dapat berujung pada resiko terbesar seperti kerusuhan dan gerakan separatis.

Indonesia merupakan salah satu negara berkembang di kawasan benua Asia. Angka Pertumbuhan ekonomi di Indonesia dibilang cukup tinggi setelah tahun 2004, dimana rata-rata angka pertumbuhan ekonomi Indonesia mencapai lebih dari 5 persen per tahun . Produk Nasional
\end{abstract}

Bruto per kapita Indonesia juga cukup tinggi jika melihat data dari BPS di tahun 2013 yaitu sebesar Rp 36.508.486,00 per tahun. Berdasarkan rumus ekonomi dalam hal menghitung pendapatan masyarakat, nilai tersebut memang benar adanya, tetapi pada faktanya tidaklah demikian. Angka tersebut merupakan bias dalam perekonomian, karena ternyata yang menyumbang PDB dalam jumlah besar hanyalah masyarakat Indonesia yang berpendapatan tinggi. Harian Kompas (22/11/2013) menyebutkan bahwa jika dikalkulasikan kekayaan 50 orang terkaya di Indonesia mencapai Rp.1.111,5 triliun. Nilai ini setara dengan setengah dari PDB Indonesia pada kuartal ke-3 2013 yaitu sebesar Rp.2.484 triliun. Jumlahnya yang hanya mencapai 0,01 persen dari penduduk Indonesia namun menyumbang hampir 50 persen PDB membuktikan bahwa ketimpangan di Indonesia tinggi walupun pertumbuhan ekonominya juga tinggi. Di bawah ini dapat dilihat perbandingan angka pertumbuhan ekonomi Indonesia dengan Index gini antara tahun 2004-2012. 


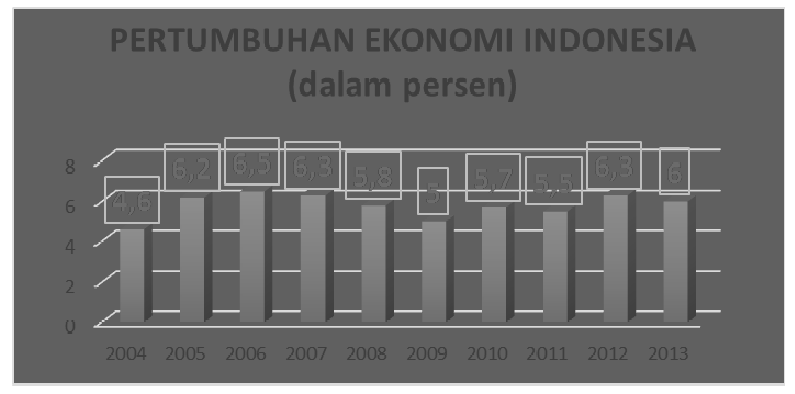

Sumber : Badan Pusat Statistik Indonesia

Gambar 1

\section{Pertumbuhan Ekonomi Indonesia 2004-2012}

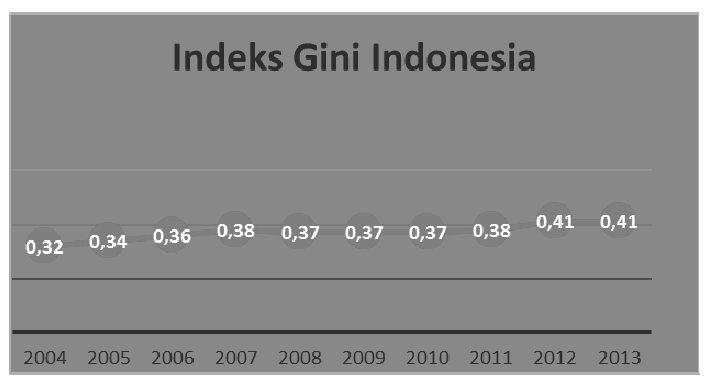

Sumber : Badan Pusat Statistik Indonesia

\section{Gambar 2}

\section{Indeks Gini Indonesia 2004-2012}

Dilema pertumbuhan ekonomi dan pemerataan pendapatan merupakan hal yang selalu dihadapi pemerintahan dalam hal meningkatkan perekonomian negaranya. Keadaan ketimpangan distribusi pendapatan maupun pertumbuhan ekonomi yang tinggi memang sangat tergantung oleh sudut pandang pemerintah itu sendiri. Heshmati (2014) menyatakan bahwa di banyak negara Asia pertumbuhan ekonomi yang tinggi akan selalu dikejar karena bagi mereka jika pertumbuhan ekonomi diprioritaskan maka nantinya pemerataan pendapatan akan berhasil Sudut pandang seperti inilah yang nantinya juga akan menentukan seberapa besar pengeluaran yang dialokasikan untuk pemerataan pendapatan.

Ada beberapa program pengeluaran pemerintah untuk mengurangi ketimpangan distribusi pendapatan. Program-program seperti bantuan pendidikan dan bantuan sosial semuanya berasal dari anggaran belanja pemerintah dimana sumber pengeluaran tersebut berasal dari pajak (Rodrigo Cubero, 2012). Di dalam buku The Role Fiskal Policy to Income Distribution (2012) lebih lanjut dijelaskan bahwa semua hal tesebut pada akhirnya tidak hanya sekedar untuk mengurangi ketimpangan distribusi pendapatan tetapi juga ikut meningkatkan kinerja perekonomian. Ini menunjukkan bahwa pengeluaran pemerintah mempunyai effect multiplier yang besar terhadap ketimpangan distribusi pendapatan.

Selainpengeluaranpemerintah, pendidikan juga terbukti menjadi salah satu faktor yang dapat mengurangi ketimpangan distribusi pendapatan. Penelitian sebelumnya yang dilakukan oleh Khan Yasir and Meenal Javed (2011) menyebutkan bahwa di China, peningkatan jumlah masyarakat yang mengenyam pendidikan menengah akan mengurangi ketimpangan distribusi pendapatan walupun di Jepang hal itu tidak secara signifikan meningkatkan pemerataan pendapatan. Di dalam literasi milik Cardozo (1993) juga dijelaskan bahwa jika perbedaan gaji yang didasarkan pada tingkat pendidikan dihilangkan, maka ketidak merataan penghasilan pekerja yang ada di Brazil dapat berkurang 50\%. Ini membuktikan bahwa tingkat pendidikan sangat menentukan pemerataan pendapatan. Penelitian ini juga menjelaskan bahwa inflasi akan mempengaruhi pemerataan distribusi pendapatan. Inflasi yang tinggi akan menyebabkan ketimpangan semakin tinggi dan sebaliknya. Pernyataan ini didukung hasil penelitian Negara (2012), namun dengan suatu syarat bahwa inflasi yang tinggi akan menyebabkan ketimpangan pendapatan semakin tinggi jika kondisi awal inflasi negara tersebut tinggi, sedangkan jika kondisi awal inflasi tersebut rendah maka inflasi yang meningkat justru akan mengurangi ketimpangan pendapatan.

Berdasarkan fakta dan penelitianpenelitian yang sudah ada, terlihat bahwa pengeluaran pemerintah, pendidikan, dan inflasi merupakan faktor-faktor penting 
yang mempengaruhi ketimpangan distribusi pendapatan. Namun demikian pengaruh tersebut berbeda pada setiap negara sehingga masalah dalam penelitian ini adalah Bagaimana pengaruh pengeluaran pemerintah, pendidikan, dan inflasi terhadap ketimpangan distribusi pendapatan di Indonesia Setelah mengetahui pengaruhnya, diharapkan penelitian ini dapat memberi masukan pada pemerintah untuk merumuskan kebijakan yang tepat dalam hal mengurangi ketimpangan distribusi pendapatan.

\section{REVIEW LITERATUR DAN HIPOTESIS}

\section{Ketimpangan Distribusi Pendapatan}

Definisi dari ketimpangan distribusi pendapatan adalah keadaan dimana hasil dari pembangunan suatu negara belum dapat dinikmati oleh rakyatnya secara merata (Setiawan Ahmad, 2011), sedangkan menurut Todaro (2000) ketimpangan distribusi pendapatan adalah belum meratanya pendapatan di seluruh kalangan masyarakat baik itu dalam bentuk kepemilikan individu maupun dalam bentuk kepemilikan faktor-faktor produksi.

World Bank mempunyai dua cara untuk menghitung ketimpangan distribusi pendapatan, yaitu sebagai berikut:

1. Terlebih dahulu menggolongkan penduduk menjadi 3 kategori yaitu

a. 40 persen penduduk berpendapatan rendah

b. 40 persen penduduk berpendapatan sedang

c. 20 persen penduduk berpendapatan tinggi

- Jika 40 persen penduduk berpendapatan rendah menerima kurang 12 cpersen dari total pendapatan pendunduk, itu artinya ketimpangan pendapatan tinggi

- Jika 40 persen penduduk berpendapatan sedang menerima 12 sampai 17 persen dari total pendapatan penduduk, itu artinya ketimpangan pendapatan sedang

- Jika 20 persen penduduk berpendapatan tinggi menerima kurang dari 17 persen dari total pendapatan penduduk, itu artinya ketimpangan rendah.

2. Menggunakan index gini atau gini ratio. Besarnya Index Gini adalah dari 0 sampai 1. Jika Index menunjukan angka 0 itu artinya tidak ada ketimpangan. sedangkan Jika Index gini menunjukkan angka 1 itu artinya seluruh pendapatan timpang ( World Bank). Berdasarkan nilai index gini diperoleh 3 kriteria sebagai berikut

- 0,50-0,70 menunjukkan bahwa ketimpangan tinggi

- 0,36-0,49 menunjukkan bahwa ketimpangan sedang

- 0,20-0,35 menunjukkan bahwa ketimpangan rendah

\section{Hasil Penelitian Sebelumnya}

Penelitian mengenai pengaruh pengeluaran pemerintah terhadap ketimpangan distribusi pendapatan dilakukan oleh Cubero (2010). Mereka meneliti pengaruh distribusi pendapatan melalui pajak dan pengeluaran sosial di negara-negara kawasan Amerika Tengah. Hasil penelitian mereka menunjukkan bahwa ternyata pajak langsung hanya beperan kecil terhadap pemerataan distribusi pendapatan, sedangkan pengeluaran pemerintah dalam hal belanja sosial mempunyai peran besar dalam pemerataan distribusi pendapatan. Hasil yang sama juga ditemukan oleh Claus, (2012) dalam penelitiannya tentang pengaruh pengeluaran pemerintah terhadap ketimpangan distribusi pendapatan di Asia, dimana peran belanja sosial lebih efektif daripada sistem pajak progresif. Hanya saja perbedaanya adalah jika di Amerika Tengah belanja sosial mengurangi ketimpangan distribusi pendapatan, tetapi di Asia justru 
sebaliknya yaitu jika pemerintah melakukan belanja sosial, justru kesenjangan pendapatan akan semakin tinggi. Higgins (2013) yang melakukan penelitian di Brazil juga menemukan bahwa pajak langsung yang ditujukan masyarakat beserta transfer yang diberikan kepada masyarakat miskin telah mengurangi angka koefisien gini sebesar 6 persen. Dari ketiga penelitian tersebut terlihat bahwa belanja pemerintah dan transfer berpengaruh terhadap ketimpangan distribusi pendapatan

The Role Fiskal Policy to Income Distribution (2012) membahas tentang bagaimana peran pendidikan terhadap program distribusi pendapatan. Belajar dari pengalaman bahwa bantuan akses pendidikan dapat membantu program distribusi pendapatan. Semua kebijakan fiskal tersebut pada akhirnya tidak hanya sekedar memeratakan pendapatan saja, tetapi juga meningkatkan kinerja perekonomian. Kinerja perekonomian tersebut terjadi karena pendapatan orang-orang miskin naik sehingga meningkatkan permintaan agregat. Pernyataan ini didukung oleh Khan (2011) yang membahas tentang pengaruh pendidikan terhadap ketidak merataan pendapatan di China dan Jepang. Hasil penelitian ini mengungkapkan bahwa di China pendidikan menengah berpengaruh signifikan terhadap distribusi pendapatan, walaupun di Jepang hal itu tidak signifikan. Ketidak signifikanan ini diduga karena variabel tesebut sudah tidak relevan atau ada faktor besar lain di luar model yang mempengaruhi ketimpangan distribusi pendapatan. Barros (1992) memperkuat pernyataan tentang peran tingkat pendidikan terhadap ketimpangan distribusi pendapatan. Dia mengatakan bahwa jika perbedaan gaji berdasarkan tingkat pendidikan dihilangkan, maka kesenjangan pendapatan pekerja akan berkurang 50 persen.

Pengaruh inflasi terhadap ketimpangan distribusi pendapatan dijelaskan oleh Cardozo (1993) Hasil penelitiannya menunjukkan bahwa di Brazil inflasi dan pengangguran yang meningkat akan mengakibatkan ketimpangan semakin tinggi. Penemuan yang berbeda terjadi di Indonesia dimana justru ketika inflasi meningkat, ketimpangan distribusi pendapatan akan menurun (Negara, 2011). Meskipun demikian sebenarnya pernyataan tersebut sangat bergantung pada kondisi awal inflasi di negeri tersebut dimana jika kondisi awal inflasi rendah, maka pengaruhnya terhadap ketimpangan distribusi pendapatan negatif sedangkan jika kondisi awal inflasi tinggi maka pengaruhnya menjadi positif. Satu lagi yang yang menjadi catatatan adalah bahwa agar pengaruhnya terhadap ketimpangan distribusi pendapatan negatif, maka inflasi yang ada tidak boleh melebihi angka 17,31 persen. Seperti dikemukakan oleh Yuyun (2011) bahwa ketika inflasi naik, maka pengeluaran penduduk kota akan mengalami kenaikan sedangkan di desa justru pendapatan naik sehingga terjadi penurunan koefisien gini.

\section{Inflasi}

Inflasi adalah suatu kondisi dimana terjadi kenaikan harga secara umum dan terus menerus. Inflasi yang stabil dan terkendali merupakan stimulus bagi perekonomian untuk tumbuh. Namun demikian apabila inflasi yang terjadi dalam perekonomian itu tidak stabil dan tinggi maka akan berdampak buruk terhadap perekonomian. Inflasi yang tinggi akan menurunkan daya beli bagi masyarakat. Selain itu menurut Cardozo (1993), inflasi juga akan berdampak bagi ketimpangan distribusi pendapatan. Hasil penelitiannya menunjukkan bahwa di Brazil inflasi dan pengangguran yang meningkat akan mengakibatkan ketimpangan semakin tinggi. Penemuan yang berbeda terjadi di Indonesia dimana justru ketika inflasi meningkat, ketimpangan distribusi pendapatan akan menurun (Negara, 2011). Meskipun demikian sebenarnya pernyataan tersebut sangat bergantung pada kondisi awal inflasi di negeri tersebut dimana jika 
kondisi awal inflasi rendah, maka pengaruhnya terhadap ketimpangan distribusi pendapatan negatif sedangkan jika kondisi awal inflasi tinggi maka pengaruhnya menjadi positif. Satu lagi yang yang menjadi catatatan adalah bahwa agar pengaruhnya terhadap ketimpangan distribusi pendapatan negatif, maka inflasi yang ada tidak boleh melebihi angka 17,31 persen. Seperti dikemukakan olehYuyun (2011) bahwa ketika inflasi naik, maka pengeluaran penduduk kota akan mengalami kenaikan sedangkan di desa justru pendapatan naik sehingga terjadi penurunan koefisien gini.

$\mathbf{H}_{\mathbf{1}}$ : Inflasi berpengaruh terhadap pemerataan distribusi pendapatan

\section{Pendidikan}

Di dalam Undang-Undang Republik Indonesia pasal 1 Nomor 20 Tahun 2003 tentang Pendidikan Nasional, pengertian pendidikan adalah usaha sadar dan terencana untuk mewujudkan suasana belajar dan proses pembelajaran agar peserta didik secara aktif mengembangkan potensi dirinya untuk memiliki kekuatan spiritual keagamaan, pengendalian diri, kepribadian, kecerdasan, akhlak mulia, serta keterampilan yang diperlukan dirinya, masyarakat, bangsa dan negara. Dengan demikian semakin tinggi tingkat pendidikan seseorang maka orang tersebut akan memiliki kemampuan yang lebih baik sehingga kesejahteraannya juga akan lebih baik. Sehingga suatu perekonomian dengan kondisi tingkat pendidikan yang tidak merata akan menyebabkan ketimpangan dalam pendapatan.

The Role Fiskal Policy to Income Distribution (2012) membahas tentang bagaimana peran pendidikan terhadap program distribusi pendapatan. Belajar dari pengalaman bahwa bantuan akses pendidikan dapat membantu program distribusi pendapatan. Semua kebijakan fiskal tersebut pada akhirnya tidak hanya sekedar memeratakan pendapatan saja, tetapi juga meningkatkan kinerja perekonomian. Kinerja perekonomian tersebut terjadi karena pendapatan orang-orang miskin naik sehingga meningkatkan permintaan agregat. Pernyataan ini didukung oleh Khan (2011)yang membahas tentang pengaruh pendidikan terhadap ketidak merataan pendapatan di China dan Jepang. Hasil penelitian ini mengungkapkan bahwa di China pendidikan menengah berpengaruh signifikan terhadap distribusi pendapatan, walaupun di Jepang hal itu tidak signifikan. Ketidak signifikanan ini diduga karena variabel tesebut sudah tidak relevan atau ada faktor besar lain di luar model yang mempengaruhi ketimpangan distribusi pendapatan. Barros (1992) memperkuat pernyataan tentang peran tingkat pendidikan terhadap ketimpangan distribusi pendapatan. Dia mengatakan bahwa jika perbedaan gaji berdasarkan tingkat pendidikan dihilangkan, maka kesenjangan pendapatan pekerja akan berkurang 50 persen.

$\mathbf{H}_{2}$ : Pendidikan berpengaruh terhadap pemerataan distribusi pendapatan

\section{Pengeluaran Pemerintah}

Pengeluaran pemerintah adalah alokasi anggaran dalam Anggaran Pendapatan dan Belanja Negara (APBN) yang disusun setiap tahunnya untuk tujuan mensejahterakan masyarakat melalui berbagai program dan proyek (Mangkusoebroto, 1999).Pengeluaran pemerintah dibedakan menjadi dua yaitu pengeluaran negara dan pengeluaran daerah, yang masing-masing mempunya struktur pengeluaran yang berbeda, sehingga dimungkinkan daerah yang memiliki anggaran pendapatan yang lebih besar akan memiliki anggaran pengeluaran yang lebih besar juga. Hal ini tentu saja untuk setiap daerah berbeda-beda. Sehingga perbedaan tersebut akan berpengaruh terhadap tingkat pendapatan di tiaptiap daerah yang pada akhirnya berdampak pada ketimpangan distribusi pendapatan. 
Penelitian mengenai pengaruh pengeluaran pemerintah terhadap ketimpangan distribusi pendapatan dilakukan oleh Cubero (2010). Cubero meneliti pengaruh distribusi pendapatan melalui pajak dan pengeluaran sosial di negara-negara kawasan Amerika Tengah. Hasil penelitian mereka menunjukkan bahwa ternyata pajak langsung hanya beperan kecil terhadap pemerataan distribusi pendapatan, sedangkan pengeluaran pemerintah dalam hal belanja sosial mempunyai peran besar dalam pemerataan distribusi pendapatan. Hasil yang sama juga ditemukan oleh Claus, (2012) dalam penelitiannya tentang pengaruh pengeluaran pemerintah terhadap ketimpangan distribusi pendapatan di Asia, dimana peran belanja sosial lebih efektif daripada sistem pajak progresif. Hanya saja perbedaanya adalah jika di Amerika Tengah belanja sosial mengurangi ketimpangan distribusi pendapatan, tetapi di Asia justru sebaliknya yaitu jika pemerintah melakukan belanja sosial, justru kesenjangan pendapatan akan semakin tinggi. Higgins (2013) yang melakukan penelitian di Brazil juga menemukan bahwa pajak langsung yang ditujukan masyarakat beserta transfer yang diberikan kepada masyarakat miskin telah mengurangi angka koefisien gini sebesar 6 persen. Dari ketiga penelitian tersebut terlihat bahwa belanja pemerintah dan transfer berpengaruh terhadap ketimpangan distribusi pendapatan

$\mathbf{H}_{3}$ : Pengeluaran Pemerintah berpengaruh terhadap pemerataan distribusi pendapatan

\section{METODE PENELITIAN}

Data yang digunakan dalam penelitian ini adalah data sekunder yang merupakan gabungan antara data time series dengan cross section. Data ini diambil dari 33 provinsi di Indonesia yang bersumber dari Badan Pusat Statistik Indonesia
(BPS). Adapun variabel yang digunakan dalam penelitian ini adalah:

1. Variabel ketimpangan distribusi pendapatan yang diukur dengan index gini dimasingmasing propinsi periode 2007-2012.

2. Variabel Inflasi dalam penelitian ini merupakan inflasi ibu kota provinsi periode 2007-2012

3. Variabel pendidikan dengan diproksikan dengan Angka Partisipasi Sekolah Perguruan Tinggi periode 2007-2012

4. Pengeluaran Pemerintah dalam penelitian ini merupakan Belanja Pemerintah Provinsi periode 2007-2012

\section{Spesifikasi Model}

Pada penelitian ini, model yang digunakan adalah regresi data panel. Data Panel adalah gabungan antara data runtut waktu (time series) dan data silang (cross section). Adapun model ketimpangan distribusi pendapatan yang akan disestimasi adalah sebagai berikut :

$\mathrm{Gn}=\beta_{0}+\beta_{1} \mathrm{In}_{\mathrm{it}}+\beta_{2} \mathrm{APS}_{\mathrm{it}}+\beta_{3} \mathrm{Bel}_{\mathrm{it}}+\mathrm{e}_{\mathrm{it}}$

Dimana

Gn = Indeks Gini Provinsi

In $=$ Inflasi Provinsi

APS = Angka Partisipasi Sekolah Provinsi

Bel = Belanja Pemerintah rutin Provinsi

e $\quad=$ Error tahun tertentu

$\beta_{0} \quad=$ Konstanta

$\beta_{1}-\beta_{3}=$ Koefisien masing-masing variabel independen

Untuk menentukan apakah metode Fixed Effect atau Random Effect yang akan digunakan dalam mengestimasi model (1) di atas maka dilakukan Uji Hausman Test. Hausman test ini digunakan untuk membandingkan antara metode Fixed Effect atau Random Effect. Berikut merupakan merupakan output dari Hausman Test: 
Tabel 1

\section{Hasil Uji Hausman Test}

Correlated Random Effects - Hausman Test

Pool: DISTRIBUSI

Test cross-section random effects

\begin{tabular}{|l|r|r|r|}
\hline Test Summary & Chi-Sq. Statistic & Chi-Sq. d.f. & Prob. \\
\hline Cross-section random & 31.592500 & 3 & 0.0000 \\
\hline
\end{tabular}

Sumber: output regresi panel data eviews 6

Berdasarkan hasil uji Hausman test di atas menunjukkan bahwa nilai probability pada tes Cross Section Random Effect memperlihatkan angka bernilai 0,000 yang berarti signifikan dengan tingkat signifikansi 95\% $\quad(\alpha=5 \%)$. Sehingga keputusan yang diambil adalah terima Ha ( $p$-value $<0.05)$ dengan hipotesis:

$\mathrm{H}_{0}$ : metode random effect

$\mathrm{H}_{\mathrm{a}}$ : metode fixed effect

Dengan kata lain metode yang dipilih dalam penelitian ini adalah metode Fixed Effect panel regresion.

\section{HASIL PENELITIAN DAN PEMBAHASAN}

Dengan menggunakan model fixed effect Panel Regresion, diperoleh hasil estimasi model faktor-faktor yang mempengaruhi ketimpangan distribusi pendapatan di Indonesia yaitu sebagai berikut:

\section{Tabel 2}

\section{Hasil Estimasi fixed effect Panel Regresion}

\begin{tabular}{lrccc}
\multicolumn{5}{c}{ Variabel Dependen : Indeks Gini } \\
\hline Variabel & Koefisien & Std. Error & t-Statistik & Prob \\
\hline Konstata & 0.236832 & 0.014997 & 15.79222 & 0.0000 \\
Inflasi & -0.002113 & 0.000517 & -4.085906 & 0.0001 \\
APS & 0.007100 & 0.000910 & 7.799658 & 0.0000 \\
Belanja & $4.63 \mathrm{E}-15$ & $1.05 \mathrm{E}-15$ & 4.386193 & 0.0000 \\
& & & & \\
R-squared & 0.756090 & & & \\
F-statistik & 14.25938 & & & \\
Prob(F-statistik) 0.00000 & & & \\
\hline
\end{tabular}

Sumber: hasil olah data
Berdasar tabel 2 dapat diketahui bahwa semua variabel independen berpengaruh signifikan terhadap ketimpangan distribusi pendapatan, dimana Inflasi berpengaruh negatif terhadap ketimpangan distribusi pendapatan sedangkan Angka Partisipasi Sekolah dan belanja pemerintah berpengaruh positif terhadap ketimpangan distribusi pendapatan.

Inflasi yang berpengaruh negatif terhadap ketimpangan distribusi pendapatan sesuai dengan penelitian sebelumnya milik Yuyun (2011) dimana ketika inflasi meningkat pengeluaran penduduk berpendapatan sedang di kota akan meningkat sehingga ketimpangan distribusi pendapatan akan berkurang. Berkurangnya ketimpangan ini diduga karena orang-orang desa merupakan pemasok barang-barang kebutuhan di kota sehingga dengan adanya kenaikan inflasi maka akan ada kenaikan pendapatan. Menurunya pendapatan orang kota dan meningkatnya pendapatan orang desa karena inflasi diduga menjadi alasan logis mengapa ketimpangan distribusi pendapatan menjadi berkurang. Sama seperti halnya dalam penelitian kali ini dimana karena data inflasi yang diambil adalah tingkat inflasi ibu kota provinsi. Ibu kota biasanya mendapat pasokan bahan pangan seperti beras, sayur dan sebagainya dari daerah/kabupaten di sekitarnya, dimana ketika terjadi inflasi di ibu kota maka akan memberikan keuntungan bagi pemasok dari daerah yang berupa kenaikan harga jual barang pasokannya. Di sisi lain harga ditingkat daerah masih relatif tetap. Kondisi ini yang mengakibatkan pendapatan daerah meningkat akibat kenaikan inflasi di ibu kota. Peningkatan pendapatan di daerah pada akhirnya akan menurunkan ketimpangan pendapatan antar daerah kabupaten/kota dalam provinsi tersebut.

Hubungan negatif inflasi terhadap ketimpangan distribusi pendapatan ini juga didukung oleh Negara (2011) dimana hubungan antara inflasi dan ketimpangan distribusi 
pendapatan sangat tergantung dengan kondisi awal inflasi. Kondisi awal inflasi yang rendah akan berpengaruh negatif dengan distribusi pendapatan dengan syarat inflasi tidak melebihi 17,31 persen. Jika dilihat dari tingkat inflasi provinsi antara tahun 2007 sampai 2012, terlihat bahwa tidak ada satu daerahpun yang inflasinya melebihi 17,31 persen. Artinya bahwa pengaruh negatif inflasi terhadap ketimpangan distribusi pendapatan merupakan hal yang wajar di Indonesia.

Hubungan positif Angka Parisipasi Sekolah dengan ketimpangan distribusi pendapatan tidak sesuai dengan penelitian-penelitian sebelumnya. Pada penelitian sebelumnya di Brazil dan China, pendidikan berpengaruh positif terhadap ketimpangan distribusi pendapatan yaitu dengan tingkat pendidikan yang semakin tinggi akan mengurangi ketimpangan distribusi pendapatan. Fenomena ini mungkin terjadi karena data Angka Partisipasi Sekolah yang digunakan dalam penelitian kali ini adalah tingkat partisipasi penduduk yang bersekolah di perguruan tinggi, yang artinya banyaknya penduduk yang belajar di perguruan tinggi di Indonesia, akan menyebabkan ketimpangan distribusi pendapatan semakin tinggi. Ada beberapa dugaan yang dapat menjawab hubungan positif tersebut.

Dugaan yang pertama adalah dapat dijelaskan oleh penelitian Barros (1992) di Brazil dimana dia mengatakan bahwa jika perbedaan gaji berdasarkan tingkat pendidikan dihilangkan, maka kesenjangan pendapatan pekerja akan berkurang 50 persen. Artinya, meskipun pendidikan bisa menjadi sarana untuk mengurangi ketimpangan distribusi pendapatan tapi hal tersebut bisa menjadi berkebalikan ketika presentasi orang yang berpendidikan tinggi semakin bertambah banyak tetapi masih lebih sedikit jika dibandingkan dengan orang-orang yang mempunyai level pendidikan di bawahnya. BPS menyebutkan bahwa sampai periode Febuari 2014 lulusan di bawah perguruan tinggi masih mendominasi angkatan kerja di Indonesia yaitu 16 persen lulusan SMA, 17,82 persen lulusan SMP, dan 46,80 persen lulusan SD. Dugaan yang kedua adalah semakin banyak lulusan perguruan tinggi, tetapi mereka tidak mempunyai kemauan untuk membuka lapangan kerja tetapi hanya mau menjadi pegawai saja. Dugaan ini juga didukung oleh Deputi Gubernur Bank Indonesia (BI) Halim Alamsyah dalam detikfinance 03/09/2012 (http:// finance.detik.com/). Dia menjelaskan bahwa sebagian besar lulusan sarjana lebih memilih mengantre untuk mendaftar menjadi Pegawai Negeri Sipil daripada menjadi pengusaha.

Dugaan yang ketiga adalah karena kebanyakan penduduk yang menjadi sarjana bekerja di luar daerah asalnya. Sedikitnya sarjana yang mau membangun daerahnya sendiri menyebabkan ketimpangan pendapatan antara mereka dan penduduk lokal akan semakin tinggi karena tidak adanya perubahan ekonomi di daerahnya.

Hubungan positif belanja pemerintah dengan ketimpangan distribusi pendapatan tidak sesuai dengan penelitian-penelitian sebelumnya, yang artinya bahwa belanja pemerintah di Indonesia justru menambah ketimpangan distribusi pendapatan. Meski demikian, ada beberapa literatur yang mampu menjelaskan mengapa fenomena tersebut bisa terjadi. Penelitian Hartono (2008) menyebutkan bahwa antara tahun 1981 sampai 2005 terjadi ketimpangan pembangunan ekonomi di Jawa Tengah yang disebabkan karena meningkatnya Dana Alokasi Pembangunan per kabupaten/kota. Dana yang bersumber dari Belanja Pemerintah Provinsi ini ternyata tidak didistribusikan secara merata dimana ada daerah yang terlalu besar mendapat bantuan dan ada daerah yang terlalu kecil mendapat bantuan. Selain itu konsentrasi dana tersebut hanya diperuntukkan untuk daerah yang sudah maju ketimbang daerah yang masih tertinggal sehingga pada akhirnya ketimpangan antar daerah akan semakin tinggi. Hasil yang 
sama juga ditemukan dalam penelitian Ayu (2014) dimana pengeluaran pemerintah yang ada di Provinsi Bali justru meningkatkan kesenjangan pendapatan kabupaten/kota . Belanja Publik yang diharapkan dapat mengurangi kesenjangan pendapatan di masyarakat justru berdampak sebaliknya. Hal ini disebabkan karena ternyata bantuan yang ada belum terjangkau dan dinikmati masyarakat secara langsung.

\section{KESIMPULAN DAN SARAN}

Berdasarkan hasil estimasi diatas dapat disimpulkan bahwa inflasi, pendidikan, dan pengeluaran pemerintah secara bersama-sama berpengaruh signifikan terhadap ketimpangan distribusi pendapatan. Variabel inflasi terbukti berpengaruh negatif dan signifikan terhadap indeks gini yang artinya jika inflasi maka ketimpangan distribusi pendapatan akan berkurang. Variabel Angka Partisipasi Sekolah dan belanja rutin terbukti berpengaruh positif .dan signifikan terhadap indeks gini yang artinya jika Angka Partisipasi Sekolah meningkat dan belanja rutin meningkat maka ketimpangan distribusi pendapatan akan meningkat.

Berdasarkan kesimpulan diatas, maka kebijakan yang disarankan adalah :

- Kenaikan inflasi yang ada perlu dipantau oleh Tim Pengendali Inflasi Daerah (TPID) sehinggameskipuninflasiterbuktimengurangi ketimpangan distribusi pendapatan namun kenaikan itu diharapakan tidak terlalu merugikan pihak yang dirugikan ketika inflasi naik. Memaksimalkan atau mempertahankan kinerja yang sudah ada wajib dilakukan oleh TPID agar kenaikan inflasi menjadi hal yang positif dalam perekonomian. Solusi untuk belanja rutin pemerintah yang terbukti menambah ketimpangan distribusi pendapatan adalah bahwa pemerintah diharapkan tidak hanya fokus pada pembangunannya tetapi pada pendistribusiaanya sehingga tidak ada perbedaan terlalu jauh antara kabupaten maju dengan kabupaten belum maju lainnya .

- Daerah yang belum maju sebaiknya menjadi prioritas utama yang mendapat alokasi pembangunan sehingga mereka dapat berkembang seperti daerah maju lainnya. Peran Bappeda juga perlu dimaksimalkan dengan cara membuat strategi anggaran yang tepat sesuai dengan karakteristik daerahnya.

- Solusi Angka Partisipasi sekolah perguruan tinggi yang menambah ketimpangan distribusi pendapatan adalah sebaiknya pemerintah daerah meningkatkan angka partisipasi sekolah yang masuk ke perguruan tinggi sampai porsinya melebihi total angka partisipasi sekolah SD, SMP, dan SMA. Selain program Bidik Misi, bantuan pendidikan untuk orang yang kurang mampu menjadi hal perlu dilakukan yaitu seperti halnya menambah bantuan melalui program "kontrak putra daerah" yang dilakukan oleh pemerintah ataupun BOS untuk perguruan tinggi seperti yang telah dilakukan di SD, SMP dan SMA.

\section{DAFTAR PUSTAKA}

Ayu I Gusti Putri dan Wahyuni,2014, Pengaruh Pengeluaran Pemerintah Dan Investasi Terhadap Pertumbuhan Ekonomi Dan Kesenjangan Pendapatan Kabupaten/ Kota di Provinsi Bali, Fakultas Ekonomika dan Bisnis Universitas Udayana.

Barros (1992), Welfare, Inequality, poverty, and social conditions in Brazil in The Last Three Decades, Paper Presented at the Brokkings Institution Conference, July 15-17 1992. Washington D.C.

Cardoso Eliana (1993), Inflation and unployment as Determinans of Inequality in Brazil, National Bureau of Economic Research. 
Claus Iris, dkk (2012), Government Fiscal Policies and Redistribution in Asian Countries, ADB Economics Working Paper Series No. 310.

Cubero, Rodrigo dan Hollar, Ivanna Vladkova, 2010, Equity and Fiscal Policy :The Income Distribution Effects of Taxation and Social Spending in Central America, IMF Working Paper.

Hartono, Budiantoro, 2008, Analisis Ketimpangan Pembangunan Ekonomi di Provinsi Jawa Tengah. Tesis Program Studi Magister Ilmu Ekonomi dan Studi Pembangunan Universitas Diponegoro

Heshmati, Almas dan Jungsuk, Kim (2014), A Survey of the Role of Fiscal Policy in Addressing Income Inequality, Poverty Reduction and Inclusive Growth, Discusion Paper No. 8119.

Higgins, Sean and Claudiney, Pereir, 2013, Analyzing the effects of fiscal policy on income inequality and poverty in Brazil. Tulane University.
Khan, Yasir dan Meenal, Javed 2011, An investigation into the determinants of inequalit and the validity of the Kuznets hypothesis. Thesis Mälardalen University Västerås,School of Sustainable Development of Society and Technology .

Negara. Radi, 2012, Analisis Pengaruh Kondisi Inflasi Terhadap Ketimpangan Distribusi Pendapatan di Negara Berkembang. Fakultas Ekonomi dan Bisnis Universitas Padjadjaran

Sofyan, M, 2010, Masalah Distribusi Pendapatan di Indonesia, Tesis Program

Magister Studi Pembangunan Universitas Gajah Mada

UNCTAD (TDR 2012). Trade and Development Report, 2012. The Role Fiskal Policy to Income Distribution . United Nations publication, New York and Geneva.

Yuyun, Rahma, 2011, Dampak Inflasi Terhadap Ketimpangan Pendapatan dan Kemiskinan di Indonesia, 19762008. Tesis S2 Magister Ekonomi Pembangunan Universitas Gajah Mada. 